\title{
尿路系腫瘍に拈ける腫瘍組織，血清および尿中の
}

carcinoembryonic antigen (CEA) について

一免疫組織化学揖よび Radioimmunoassay による検討一

兵庫医科大鸴熦显器科学教室 鹿子 木 基 二

\section{CARCINOEMBRYONIC ANTIGEN (CEA) IN TUMOR TISSUE, SERUM AND URINE \\ IN CASES WITH TUMORS OF THE URINARY TRACT}

-A Study by Immunohistochemistry and Radioimmunoassay-

\author{
Mototsugu Kanokogi \\ Department of Urology, Hyogo College of Medicine, Nishinomiya, Japan \\ (Director: Prof. Fumihiko Ikoma)
}

In order to evaluate the diagnostic and prognostic significance of carcinoembryonic antigen (CEA), an immunohistochemical study, using the peroxidase-antiperoxidase (PAP) method, of localization of CEA on tissue sections in one hundred and forty-six cases with primary tumors of the bladder, ureter, and renal pelvis was performed. In addition, in some of the cases, CEA values in serum, urine, and tumor tissue extract were also examined by radioimmunoassay.

The following results were obtained:

1) Immunohistochemically, CEA-positive tumor cells were found in 63 of 127 transitional cell carcinomas (TCC), 3 of 4 adenocarcinomas, and all of 5 squamous cell carcinomas, but not in any other malignant nor benign tumors.

2) Concerning the primary sites of the tumors, there was no significant difference in the incidence and distribution of CEA-positive tumor cells among TCC of bladder, ureter, and renal pelvis.

3) In TCC, CEA-positivity in the tumor cells correlated significantly to the histological grade $(p<0.005)$, pathological stage $(p<0.005)$, and occurrence of local recurrence $(p<0.025)$. Therefore, CEApositivity in the tumor cells seems to be a parameter for the malignant potentiality of the tumor.

4) In TCC of the bladder, there was no significant correlation between CEA-positivity in the tumor cells and values of serum and/or urinary CEA, showing that these three parameters are independent of each other.

5) In TCC of the bladder, although both values of serum and urinary CEA were not satisfactory as diagnostic information, the former was elevated significantly in cases with distant metastasis $(\mathrm{p}<0.05)$, and the latter in high stage cases with muscular invasion $(\mathrm{p}<0.05)$.

6) CEA was thought to be a more specific tumor marker in urachal carcinoma than in TCC because of its high concentration in the serum and tumor tissue extract. On the other hand, in mesonephric adenocarcinoma it was not detected immunohistochemically. These findings suggest embryologically different pathogeneses of the two adenocarcinomas.

要旨: 原発性尿路腫瘍146例を対象として, 酵素抗体法(PAP 法)を用いて免疫組織化学的に carcinoembryonic antigen (CEA) の検索を行ない, 併せて一部の症例で, 血清, 尿中および腫瘍組織中の CEA を Radioimmunoassay 法を用いて測定し，以下の結果を得た。

(I) PAP 法によって, 腫瘍内 CEA は, 移行上皮癌 $(63 / 127)$, 腺癌 $(3 / 4)$, 扁平上皮癌 $(5 / 5)$ に検 出されたが, その他の悪性腫瘍や良性病变には検出されなかった。

（II）移行上皮癌の原発部位別では, 膀胱・尿管・腎盂腫瘍の間で腫瘍内 CEA の陽性率やその局在に有 
意差はみられず, CEA 産生能の面で各腫瘍の類似性を示すものと考兄られた。

(III) 移行上皮癌において, 腫瘍内 CEA の有無は, 組織学的異型度 $(\mathrm{p}<0.005)$, 深達度 $(\mathrm{p}<0.005)$ および局所再発の有無 $(\mathrm{p}<0.025)$ との間に相関がみられ, 腫瘍の悪性度を表わす parameter となり得 ると考えられた。

(IV) 膀胱移行上皮癌では, 腫瘍内 CEA の有無, 血清 CEA 值および尿中 CEA 值の三者の間には相関 はみられなかった。

(V) 膀胼移行上皮癌では，血清扣よび尿中 CEA 值はともにスクリーニングテストとしての特異性は 乏しいが，前者は遠隔転移の出現とともに $(\mathrm{p}<0.05)$, 後者は high stage 群で $(\mathrm{p}<0.05)$ 有意に高值を 示した.

(VI) 腺癌のらち, 尿膜管癌では移行上皮癌に比べ CEA のもつ特異性は大きいと考えられるが, 中腎 癌では証明されず，両者の発生母地の相違を示唆するものと思われた。

\section{緒 言}

Carcinoembryonic antigen(以下, CEA と略す)は, 1965年 Gold ら ${ }^{12)}$ によって結腸癌組織から抽出され, これが胎児消化管上皮にも存在することから癌胎児性 抗原と命名された。当初 Gold らは, CEA が内胚葉由 来消化器癌と胎児消化管上皮に共通した特異抗原と考 えていたが，その後消化器癌以外の悪性腫瘍のみなら ず非癌組織中 ${ }^{3) \sim 5)}$ にも存在することが明らかにされて 来た。

その後の研究で, CEA の物理化学的性状は, $\beta$ globulin 域に電気泳動される分子量約20万の過塩素酸 溶解性の糖蛋白とされているが，糖組成などに不均一

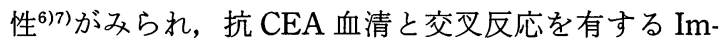
munoreactive CEA として $\mathrm{NCA}^{8)}, \mathrm{NFA}^{9)}, \mathrm{NCA}-2^{10}$ などの CEA 関連物質が正常組織から抽出されたこと から, 免疫学的にはその抗原決定基は単一ではなく， 同定，定量に際し複雑な背景のあることが指摘される ようになった。

臨床的には，Radioimmunoassay 法による CEA 定 量法が広く応用されるようになってから，種々の悪性 腫瘍に対して検討され，特に結腸直腸癌，㬸癌，＼cjkstart胆管 癌などでは血清 CEA 值は高值を示しその診断的価値 は大きいが，同時に非癌症例にも検出されることがわ かり6(7)11), 問題点が指摘されている.

泌尿器科領域に括いても，尿路悪性腫瘍症例に打け る血清打よび尿中 CEA についての報告は多くみられ るが12) 19)，そのスクリーニングテストとしての価值は 乏しいとする報告も散見される201 23)。しかし，いまだ 尿路系腫瘍全般に拈いて腫瘍組織内 CEA の有無につ いての報告はなく，また腫瘍組織内 CEA の有無と血 清䏠よび尿中 CEA 值との関連も不明である。そこで, 尿路悪性腫瘍の診断・予後判定に括ける CEA の有用
性と問題点を明らかにする目的で, 原発性膀胼・尿管・ 腎孟腫瘍を対象にして免疫組織化学的方法により腫瘍 組織内 CEA の局在を検討し，併せて一部の症例で腫 瘍組織，血清および尿中 CEA を測定した。

\section{対象および方法}

I. 対象.

昭和 48 年 7 月から昭和 58 年 8 月までに兵庫医科大学 泌尿器科を受診した原発性尿路腫瘍症例のうち, 明確 な組織診断の下されている146例を対象とした。平均年 龄は63.5歳で, 性別では男子113例, 女子33例であった。 その組織分類は, 膀胼腫瘍 125 例のうち, 移行上皮癌 (以下, TCC と略す) 107例, 腺癌 (以下, $\mathrm{AC}$ と略す) 4 例(尿膜管癌 3 例, 中腎癌 1 例), 扁平上皮癌(以下, $\mathrm{SCC}$ と略す） 5 例, 未分化癌 1 例, 肉腫 2 例（横紋筋 肉腫 1 例, 平滑筋肉腫 1 例), 悪性リンパ腫 1 例, 移行 上皮乳頭腫 5 例であった。尿管腫瘍 12 例では, TCC 11 例，移行上皮乳頭腫 1 例，そして腎㙉腫瘍 9 例は全例 TCCであった. TCCのうち, いわゆる papillomatosis の像を呈し, 原発巣が確定し得ない症例は対象から除 外した。

手術時摘除された組織から 1 症例につき， $1 \sim 8$ 個 の病理標本を作製し組織診断を決定したが，この中に は腫瘍病変とは別に, 増殖性膀胱炎 (Cystitis cystica and glandularis 11例, von Brunn's nest 8 例) が含 まれていた。

II. 方法.

(A) 酵素抗体法 (PAP 法):

摘除材料は，10\%ホルマリン固定，パラフィン包埋 後, ミクロトームで $4 \sim 5 \mu$ の厚さに薄切し, 低温伸展板 上で乾燥させた。薄切標本は, 一夜 $37^{\circ} \mathrm{C}$ の incubator 内 に静置した後, 酵素抗体法による検索に供した。

CEA の組織内局在は, Sternberger らの Perox- 
idase-antiperoxidase (PAP) 法 ${ }^{24)}$ で検索した。 即ち, キシロールで脱パラフィン後, $0.3 \% \mathrm{H}_{2} \mathrm{O}_{2}$ 添加メタ ノール中に 30 分間浸漬し内因性ペルオキシダーゼを除 去した後， $5 \%$ 正常ブタ血清を 10 分間作用させ非特異 的抗原抗体反応をブロックした. 次いで，抗 CEA 血清 （rabbit anti-human CEA）を30分間湿室内で反応さ せ, Tris buffer ( $\mathrm{pH} 7.6)$ で充分洗浄した後, 第 2 抗 体 (swine anti-rabbit immunoglobulin), PAP 溶液 （rabbit, PAP）を順次同様に作用させた。抗原抗体反 応は全て $37^{\circ} \mathrm{C}$ incubator 内で作用させた。このあと，

3, 3'-diaminobenzidine $4 \mathrm{HCl} 20 \mathrm{mg}$ 添加 Tris buffer (pH 7.6) $100 \mathrm{ml}$ に, $7 \% \mathrm{H}_{2} \mathrm{O}_{2}$ 水溶液 $0.1 \mathrm{ml}$ を加六た 溶液中に 2 分間浸漬し, 呈色反応させた。 Tris buffer で反応を停止させた後，へマトキシリンで核染色し， 脱水, 透徹, 封入した。

対照試験 ${ }^{25}$ は，抗 CEA 血清の代わりに非免疫正常 ウサギ血清（1：200）拈よびTris bufferを用いて染 色し，それぞれ非特異的反応のないことを確かめた。 また，第 2 抗体を削除して染色し，非特異的反応のな いことを確かめた。ささらに, 後述する結腸癌肝転移組 織から過塩素酸で抽出した CEA による抗 CEA 血清 の吸収操作で, 陽性所見の消失することを確認した。 陽性コントロールには結腸癌組織（3 例）を, 陰性コ ントロールには正常肺 ( 2 例) 䑚よび正常膀胱組織 ( 8 例）を用いた。

(B) 過塩素酸抽出法：

手術で得られた膀胱腫瘍組織（計 $28.0 \mathrm{~g}$ ), 尿管腫瘍 組織 (計 $3.9 \mathrm{~g}$ ), 非癌膀胱粘膜 (計 $9.6 \mathrm{~g})$ お。び剖検で 得た結腸癌肝転移組織( 計 $5.9 \mathrm{~g}$ ), 正常七ト肺および脾 組織をー $80^{\circ} \mathrm{C}$ deep freezer 内にプールして招き，これ らの組織から von Kleist $ら^{26)}$ の方法に準じ過塩素酸 抽出物を得た. 即ち, 組織の wet weight を測定後, 1 ～ 5 倍量の生理食塩水を加光水冷下にブレンダーで homogenize し, これに等量の $2 \mathrm{M}$ 過塩素酸を加兄, 30 分間上く擋汼した後, $4{ }^{\circ} \mathrm{C}$ で30分間遠心 $(12,000 \mathrm{rpm})$ した。得られた上清をTris hydroxymethyl aminomethane で中性化した後, 飽和硫酸アンモニウ ムで塩析させた。つづいて $4{ }^{\circ} \mathrm{C} て ゙ 30$ 分間遠心 $(12,000$ $\mathrm{rpm}$ )し, 得られた沈渣を蒸留水で洗浄して余剰の過塩 素酸を除去し, 再び $4{ }^{\circ} \mathrm{C}, 30$ 分間遠心 $(12,000 \mathrm{rpm})$, その沈渣から涷結乾燥粉末を得た。

(C) 抗血清 :

用いた抗血清は全て DAKOPATTS 社製 (Denmark）を用いた。抗 CEA 血清 (rabbit anti-human CEA)
は, nonspecific crossreacting antigen $(\mathrm{NCA})^{8)}$ を除 去するために, 上述の正常ヒト肺拉よび脾の過塩素酸 抽出凍結乾燥粉末 $(25 \mathrm{mg} / \mathrm{ml}$ antiserum), 执よび正常 ヒト血清凍結乾燥粉末 $(50 \mathrm{mg} / \mathrm{ml}$ antiserum) を加光, $4{ }^{\circ} \mathrm{C}$ で24時間吸收させた。 PAP 法に用いた抗血清の希 釈濃度は, 抗 CEA 血清 $1: 400$, 第 2 抗体 $1: 20$, PAP 溶液 $1 ： 100$ とした。

(D) CEA の Radioimmunoassay:

CEA定量は, CEA - RIAKIT (Dainabot Radioisotope Laboratories, Ltd., Tokyo.) を用い, い わゆるサンドイッチ法による Radioimmunoassay ${ }^{11)}$ 測定した。血清および尿検体は測定までー $20^{\circ} \mathrm{C} て ゙$ て東結 保存して和いた。尿検体は早朝第 1 尿を検体とした。 組織内 CEA の測定は, 上述の過塩素酸抽出凍結乾燥 粉末を蒸留水に希釈し，これをサンプルとした。尿サ ンプルについては，健康人尿に各種既知量の CEA を 加光測定した結果, その回収率は106.8\%であったこと やまた血清サンプルと同じ希釈曲線が得られたこと から，尿中 CEA 測定に際して非特異的反応はないも のと考えられた，過塩素酸抽出による組織内 CEA の 測定に際し，希釈系列を用いた複数点測定で各測定值 が標準曲線上にプロットされたことから，非特異的反 応はないものと考光られた。

\section{結 果}

膀胼腫瘍の組織分類は, 膀胱癌取扱い規約に準じた。 TCC の組織学的異型度は, 細胞異型度, 構造異型度よ り G1から G3まで分類した。膀胱腫瘍の組織学的深達 度の判定に際し, TUR 材料では筋層内浸潤のうち浅 層までにとどまるものか，深層にまで及ぶものか明確 でない例がみられたため，pT2と pT3を一括して pT $2 / 3$ と分類した。また，尿管，腎孟腫瘍では粘膜固有層 内にとどをるものを non-invasive, 筋層内浸潤を認め るものを invasive と分類した。

（1）酵素抗体法（PAP 法）:

PAP法によってCEA 陽性細胞は茶褐色に染色さ れるが，陽性細胞が標本中の腫場の $10 \%$ 以上を占めた 場合を強陽性，10\%以下の場合を弱陽性とした。 CEA 陽性細胞の核はいずれも陰性であった。

PAP 法による腫瘍組織内 CEA の検出結果を Table 1に総括した. CEA 陽性所見は, TCC, AC, SCC にみられたが,その他の組織型では全て陰性であった。

(a) 移行上皮癌：

TCC 127例のうち, CEA 陽性を示したのは63例 (50\%) で，原発部位別では，膀胀腫瘍49\% (52/107), 
Table 1 Results of Immunoperoxidase Stain for CEA in Malignant and Non-malignant Lesions of Bladder, Ureter, and Renal Pelvis.

\begin{tabular}{|c|c|c|c|c|}
\hline & \multirow{2}{*}{$\begin{array}{l}\text { No. of } \\
\text { cases }\end{array}$} & \multirow{2}{*}{ CEA-Positive } & \multicolumn{2}{|c|}{ CEA Positive } \\
\hline & & & tumor cells $<10 \%$ & tumor cells $>10 \%$ \\
\hline \multicolumn{5}{|l|}{ Bladder } \\
\hline Transitional cell carcinoma & 107 & $52(49 \%)$ & $26(24 \%)$ & $26(24 \%)$ \\
\hline Adenocarcinoma : & & & & \\
\hline Urachal carcinoma & 3 & $3(100 \%)$ & 0 & $3(100 \%)$ \\
\hline Mesonephric carcinoma & 1 & 0 & & \\
\hline Squamous cell carcinoma & 5 & $5(100 \%)$ & 0 & $5(100 \%)$ \\
\hline Undifferentiated carcinoma & 1 & 0 & & \\
\hline \multicolumn{5}{|l|}{ Sarcoma : } \\
\hline Rhabdomyosarcoma & 1 & 0 & & \\
\hline Leiomyosarcoma & 1 & 0 & & \\
\hline Malignant lymphoma & 1 & 0 & & \\
\hline Transitional cell papilloma & 5 & 0 & & \\
\hline \multicolumn{5}{|l|}{ Proliferative lesions : } \\
\hline Cystitis cystica \& glandularis & 11 & 0 & & \\
\hline Brunn's nest & 8 & 0 & & \\
\hline \multicolumn{5}{|l|}{ Ureter } \\
\hline Transitional cell carcinoma & 11 & $6(55 \%)$ & $3(27 \%)$ & $3(27 \%)$ \\
\hline Transitional cell papilloma & 1 & 0 & & \\
\hline \multicolumn{5}{|l|}{$\underline{\text { Renal Pelvis }}$} \\
\hline Transitional cell carcinoma & 9 & $5(56 \%)$ & $3(33 \%)$ & $2(22 \%)$ \\
\hline
\end{tabular}

Table 2 Correlation between the Results of Immunoperoxidase Stain for CEA and Histological Grade of Transitional Cell Carcinomas of Bladder, Ureter, and Renal Pelvis.

\begin{tabular}{l|c|c|c|c|c}
\hline & \multirow{2}{*}{ Grade } & \multirow{2}{*}{$\begin{array}{c}\text { No. of } \\
\text { cases }\end{array}$} & \multirow{2}{*}{$\begin{array}{l}\text { CEA- } \\
\text { Positive }\end{array}$} & \multicolumn{2}{|c}{ CEA-Positive } \\
\cline { 5 - 6 } & & & & tumor cells $<10 \%$ & tumor cells $>10 \%$ \\
\hline TCC of Bladder & G1 & 12 & 0 & & \\
TCC of Ureter & G2 & 68 & $34(50 \%)$ & $20(29 \%)$ & $14(21 \%)$ \\
& G3 & 27 & $18(67 \%)$ & $6(22 \%)$ & $12(44 \%)$ \\
TCC of Renal Pelvis & G1 & 0 & 0 & & \\
& G2 & 6 & $3(50 \%)$ & $1(17 \%)$ & $2(33 \%)$ \\
& G3 & 5 & $3(60 \%)$ & $2(40 \%)$ & $1(20 \%)$ \\
& G1 & 0 & 0 & & \\
& G2 & 4 & $2(50 \%)$ & $2(50 \%)$ & 0 \\
& G3 & 5 & $3(60 \%)$ & $1(20 \%)$ & $2(40 \%)$ \\
\hline
\end{tabular}

尿管腫瘍55\%（6/11），腎孟腫瘍56\%（5/9）に陽性で， これらの陽性率の間には推計学的に有意差は認めな かった ( $\chi^{2}$ 検定). TCC に打ける腫瘍内 CEA の局在 は，1）腫瘍細胞の細胞膜表面に強く染色されるもの (Fig. 1)，2）細胞質内が diffuse に染色されるもの （Fig. 2）に大別されたが，膀脱・尿管および腎孟原発 腫瘍の間で腫瘍内 CEA の局在に明らかな差はみられ なかった。

TCC に括ける腫瘍内 CEA 陽性率と組織学的異型
度の関係は Table 2に示すように，膀胱腫瘍では $\mathrm{G} 1$ 12例は全例 CEA 陰性であったのに対し，G3では67\% （18/27）に陽性で，このうち強陽性を示す例が $44 \% を$ 占めていた。 TCC 127例に拈いて，異型度の悪化と腫 瘍内 CEA 陽性率の間には有意の相関がみられた $(\mathrm{p}<$ $0.005, x^{2}$ 検定). 同様に, 深達度との関係は Table 3 に示す如く, 粘膜固有層内にとどする low stage 群と, 筋層内浸潤を伴う high stage 群の間では各群の陽性 率は，膀胱腫瘍では36\% (21/58),63\%（31/49）, 尿管 
Table 3 Correlation between the Results of Immunoperoxidase Stain for CEA and Pathological Stage of Transitional Cell Carcinomas of Bladder, Ureter and Renal Pelvis.

\begin{tabular}{|c|c|c|c|c|c|}
\hline & \multirow{2}{*}{ Stage } & \multirow{2}{*}{$\begin{array}{l}\text { No. of } \\
\text { cases }\end{array}$} & \multirow{2}{*}{$\begin{array}{l}\text { CEA- } \\
\text { Positive }\end{array}$} & \multicolumn{2}{|c|}{ CEA-Positive } \\
\hline & & & & tumor cells $<10 \%$ & tumor cells $>10 \%$ \\
\hline \multirow[t]{4}{*}{ TCC of Bladder } & $\mathrm{pT}$ is & 2 & 0 & & \\
\hline & pT1 & 56 & $21(37 \%)$ & $12(21 \%)$ & $9(16 \%)$ \\
\hline & $\mathrm{pT} 2 / 3$ & 41 & $26(63 \%)$ & $12(29 \%)$ & $14(34 \%)$ \\
\hline & $\mathrm{pT} 4$ & 8 & $5(63 \%)$ & $2(25 \%)$ & $3(38 \%)$ \\
\hline \multirow[t]{2}{*}{ TCC of Ureter } & non-invasive ${ }^{*}$ & 3 & $1(33 \%)$ & $1(33 \%)$ & 0 \\
\hline & invasive ${ }^{* *}$ & 8 & $5(63 \%)$ & $2(25 \%)$ & $3(38 \%)$ \\
\hline \multirow[t]{2}{*}{ TCC of Renal Pelvis } & non-invasive* & 3 & $1(33 \%)$ & $1(33 \%)$ & 0 \\
\hline & invasive** & 6 & $4(66 \%)$ & $2(33 \%)$ & $2(33 \%)$ \\
\hline
\end{tabular}

* Tumor within the lamina propria

** Tumor invaded into the musculature

腫腸では33\% (1/3), 63\% (5/8), 腎孟腫瘍では $33 \%$ (1) 3), 66\%（4/6）であり，TCC 127例に扔いては high stage 群で有意（ $\mathrm{p}<0.005, \chi^{2}$ 検定）に高い陽性率で あった．以上の結果から，PAP 法による腫瘍内 CEA の存在と TCC の異型度・深達度の間には相関がある ものと考えられた。

次に, 膀脱 TCC に拈いて, 局所再発の有無と腫瘍内 CEAについて検討した (Table 4). 対象は, 組織学的 深達度が pT1で，全例 TURによって原発巣が根治的 に摘除されたものと考えられる症例 38 例 $(\mathrm{G} 17$ 例, G2 31例）で，らち34例に術後制癌剂注入療法を施行して いる.このらち, 術後 2 年以内に局所再発を来した症 例を有再発群とした，局所再発は18例（47\%）にみら れ，このらち腫瘍内 CEA 陽性群の73\%（11/15）に再 発がみられたのに対し，陰性群では $30 \%(7 / 23)$ の再 発率であり, 両群の間には有意の差 $\left(\mathrm{p}<0.025, \chi^{2}\right.$ 検 定）を認めた（Table 4A). 局所再発の有無を Grade 別にみると (Table 4B), G2 (16/31) はG1 (2/7) に 比べ再発率は高い傾向にあったが，推計学的には有意 差は証明できなかった。このことから，腫瘍内 CEA の 有無は, 再発の有無の点から腫瘍の悪性度を表わす 1 つの指標になり得ると考えられた。

腫瘍の発育様式からみて，一般に非乳頭状癌は肉眼 的に病変を把光難く, 浸潤癌となって初めて臨床診断 がつくことが多いことから, 乳頭状癌とは違った特徵 を有している27)28)．107例の膀脱 TCC のうち非乳頭状 増生を示したものは10例にみられた。このらち carcinoma in situ (G2, 2 例) は CEA 陰性であったが, 非乳頭状浸潤癌では $50 \%$ （4/8）に陽性であり，乳頭状 癌と比べて発育様式の違いによる腫瘍内 CEA 陽性率
Table 4

A : Correlation between Results of Immunoperoxidase Stain for CEA and Local Recurrence in Stage pT1 Cases of Bladder Tumors

\begin{tabular}{l|c|c|c}
\hline Recurrence & $\begin{array}{c}\text { No. of } \\
\text { cases }\end{array}$ & $\begin{array}{c}\text { Negative } \\
\text { stain } \\
\text { for CEA }\end{array}$ & $\begin{array}{c}\text { Positive } \\
\text { stain } \\
\text { for CEA }\end{array}$ \\
\hline $\begin{array}{l}\text { Without } \\
\text { With }\end{array}$ & 20 & 16 & 4 \\
\hline Total & 38 & 7 & 11 \\
\hline \multicolumn{2}{c}{$\left(\chi_{2}=5.09, \mathrm{p}<0.025\right)$}
\end{tabular}

B : Correlation between Histological Grade and Local Recurrence in Stage pT1 Cases of Bladder Tumors

\begin{tabular}{c|c|c|c}
\hline Recurrence & $\begin{array}{c}\text { No. of } \\
\text { cases }\end{array}$ & G1 & G2 \\
\hline Without & 20 & 5 & 15 \\
With & 18 & 2 & 16 \\
\hline Total & 38 & 7 & 31 \\
\hline \multicolumn{2}{c}{$\left(\chi^{2}=0.467\right.$, N.S. $)$}
\end{tabular}

の差は見出せなかった。

（b）腺癌：

AC 4 例には, 尿膜管癌 3 例, 中腎癌 1 例が含まれ た。尿膜管癌では全例に腫瘍内 CEA が強陽性に検出 され, 腫湯細胞膜表面や細胞質内が強く染色された他 に，管状構造を示す部の腺腔内分泌物（Fig. 3）や， mucinous adenocarcinoma の像を示す部の粘液も陽 性に染色された，尿膜管癌では，TCC に比べ CEA 陽 性所見が著明に強いのが特徵であった。これに対し， 中腎癌では既に報告 ${ }^{29}$ したように, glandular component も clear cell component むともにCEA 陰 
Fig. 1 Transitional cell carcinoma of bladder, G3. CEA is stained intensely both in the cytoplasm and apical surface of the tumor cells. (PAP method, counterstained with hematoxylin, $\times$ 240.)

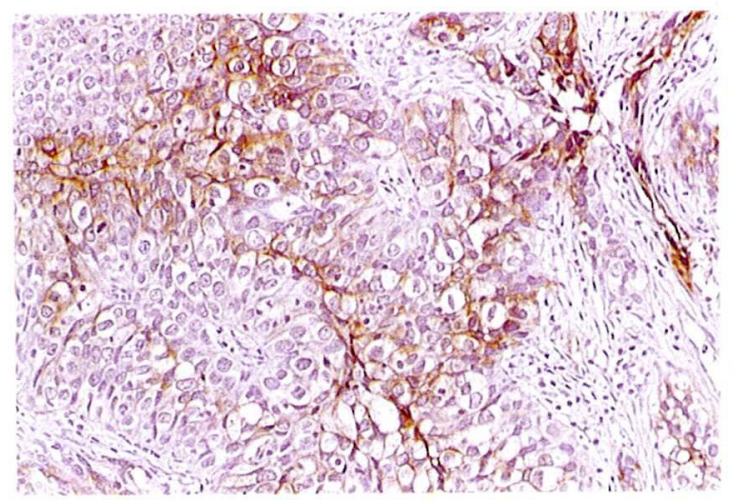

Fig. 3 Adenocarcinoma (urachal carcinoma) of bladder. CEA-positive findings are shown in the glandular luminal surface as well as in the tumor cytoplasm. (PAP method, counterstained with hematoxylin, $\times 240$.)

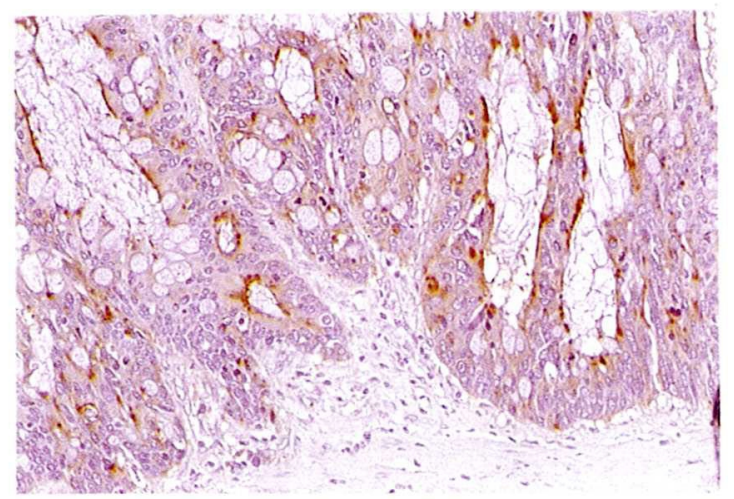

性であった。

(C) 扁平上皮癌:

$\mathrm{SCC} 5$ 例の全例で一部に TCC の混在を認めた。腫 瘍内 CEA は SCC の全例に検出され, 角化傾向を示す 高分化な部位も (Fig. 4A), 角化を示さないより未分 化な腫瘍細胞も（Fig. 4B）ともに陽性に染色された. コントロールとした正常扁平上皮（食道，喉頭）およ び膀胱扁平上皮化生では, 角化層以下の基底細胞層に 陽性所見はみられずCEA 陰性と判定したが, 表層の 角化層に限局して陽性所見がみられ非特異的反応と考
Fig. 2 Transitional cell carcinoma of bladder, G2. CEA is stained diffusely in the cytoplasm of the tumor. (PAP method, counterstained with hematoxylin, $\times 240$ )

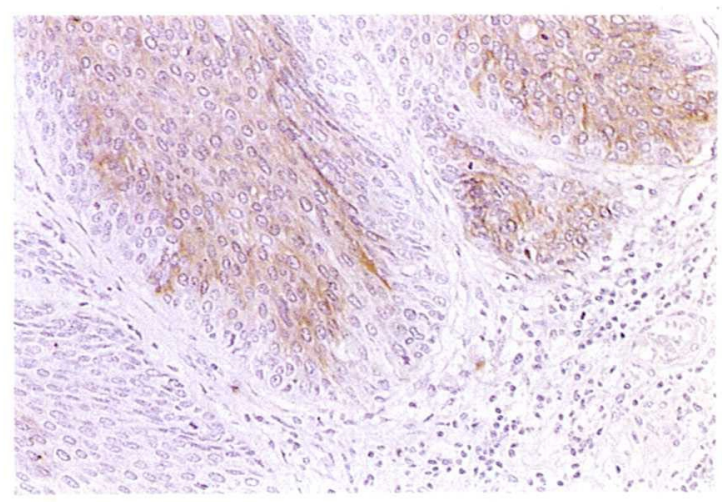

Fig. 4 Squamous cell carcinoma of bladder. CEA is positive in the keratinizing (A) and non-keratinizing (B) squamous cell carcinoma cells. (PAP method, counterstained with hematoxylin, $\times 480$.)

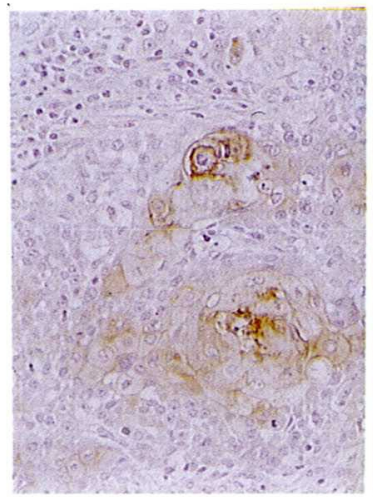

(A)

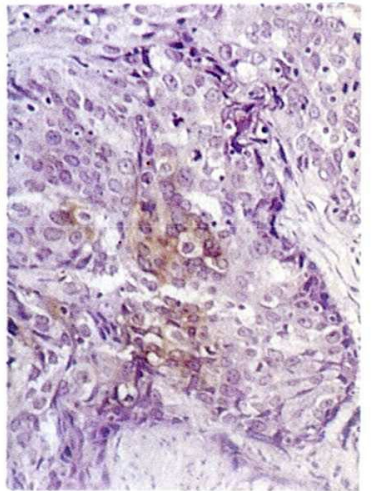

(B)
光られた。

（d）その他の組織型:

TCC, AC, SCC 以外の悪性腫瘍で CEA が陽性に染 色されたものはみられなかった。

移行上皮乳頭腫(膀胱 5 例, 尿管 1 例)では全例 CEA 陰性であった。

また, 腫瘍病変に隣接して増殖性膀脱炎（von Brunn's nest 8 例, Cystitis cystica and glandularis 11例）がみられたが，これらも全例陰性であった。

(2) 組織内 CEA の Radioimmunoassay : 
手術材料から得た膀胱 TCC ( 4 例, 計 $20.5 \mathrm{~g}$ ), 膀脱 $\mathrm{AC}(1$ 例, 計7.5g), 尿管 TCC ( 3 例, 計 $3.9 \mathrm{~g}$ ) の腫 瘍組織, および剖検より得た結腸腺癌肝転移組織 (1 例, 計 $5.9 \mathrm{~g}$ )から前述した過塩素酸抽出法で CEA を抽 出し, Radioimmunoassay 法で組織内 の Immunoreactive CEA を測定した。同時に, 膀胱腫瘍で全摘除 術を受けた膀胼から肉眼的に腫瘍と離れた非癌膀胱粘 膜（ 3 例，計 $9.6 \mathrm{~g}$ ）を採取し，同様に測定した。 上述 の手術材料より得た腫瘍組織は, 1 症例当りごく少量 の例が含まれたため, 各腫瘍組織を一括してプールし て検体とし CEA 抽出操作を行なったため, 各症例間 の CEA 量の有意差は検定できなかった．各腫瘍にお ける腫瘍内 Immunoreactive CEA 量の結果は Table 5に示すように, 膀胱 $\mathrm{AC}$ 中の濃度は720ng/g wet wt. で, 結腸腺癌中の $1,119 \mathrm{ng} / \mathrm{g}$ wet wt. に匹敵する量が 認められたのに対し，TCCでは極めて少量しか検出さ れなかった。

（3）血清 CEA :

膀脱 TCC 無転移例59例, 膀脱 TCC 有転移例14例,
膀胱 AC 4 例，尿管 TCC 5 例, 腎孟 TCC 7 例につ いて血清 CEA 值を測定した。対照群とした良性疾患 28例についての結果も併せて Fig. 5 にまとめた。測定 平均值はいずれの悪性腫瘍群も良性疾患群に比べ高 く, 特に膀胱 TCC 有転移群, 膀胱 $\mathrm{AC}$ 群では各々 $10.51 \pm 13.40 \mathrm{ng} / \mathrm{ml}, 5.48 \pm 3.32 \mathrm{ng} / \mathrm{ml}$ と高值を示し た。良性疾患群との間で平均值の差を検定してみると ( $\mathrm{F}$ 検定), 膀脱 TCC 無転移群 $(\mathrm{p}<0.01)$ ，有転移群

Table 5 Immunoreactive CEA in the Tissues of Urothelial Malignancies, Non-malignant Bladder Mucosa and Colonic Carcinoma.

\begin{tabular}{l|c}
\hline & $\begin{array}{c}\text { Immunoreactive CEA } \\
\text { (ng/wet weight) }\end{array}$ \\
\hline TCC of Bladder* & 3.8 \\
AC of Bladder** & 720 \\
TCC of Ureter* & 8.4 \\
Non-malignant Bladder Mucosa & 2.0 \\
Colonic Carcinoma & 1119 \\
\hline \multicolumn{2}{c}{ * Transitional cell carcinoma } \\
\multicolumn{2}{c}{ ** Adenocarcinoma }
\end{tabular}

Fig. 5 Levels of Serum CEA in the Cases with Urothelial Tumors and Benigh Diseases.

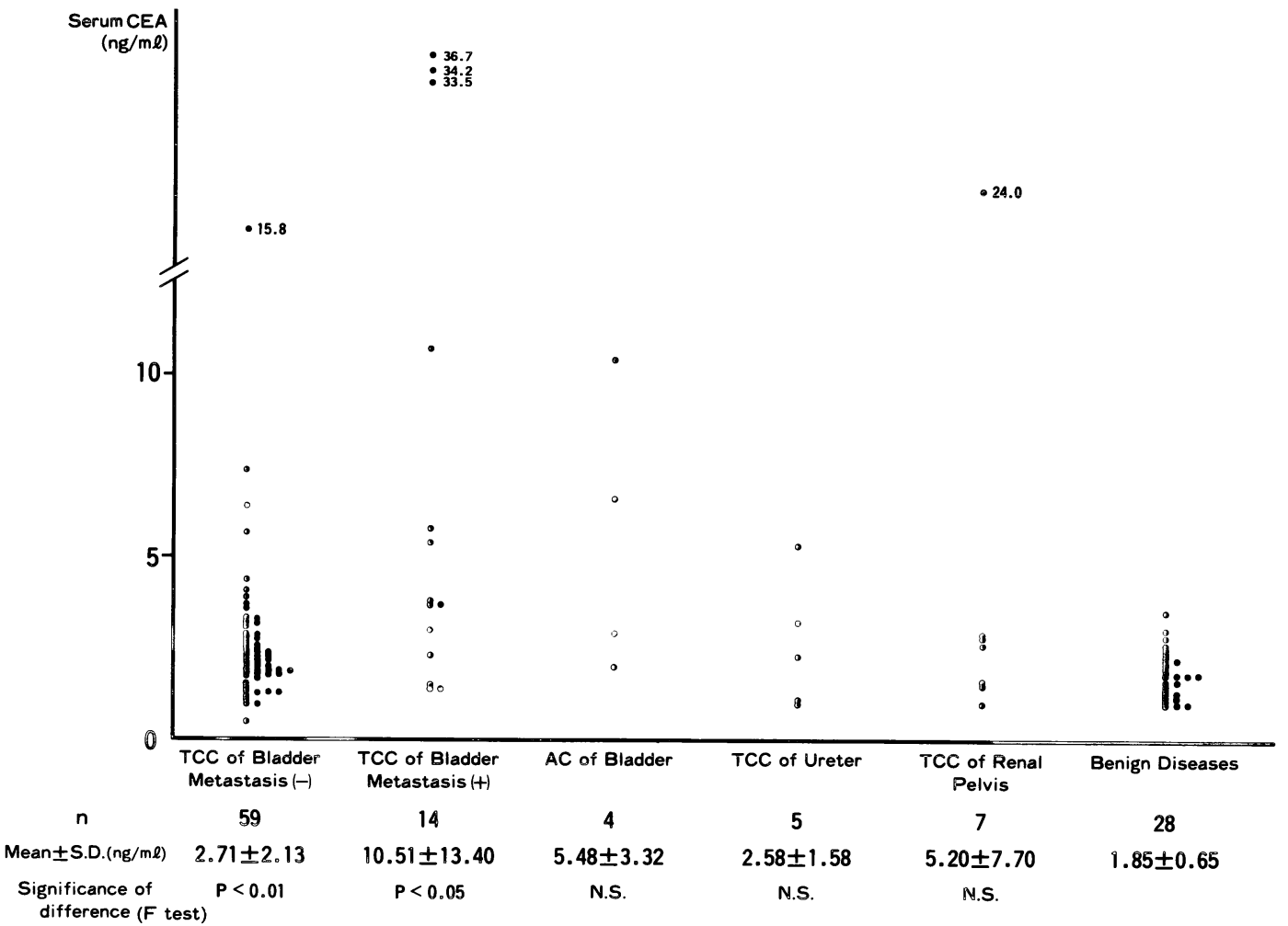


（p＜0.05）で有意の差を認めたが，その他の群では有 意差を証明できなかった。

膀胱 TCC 無転移群59例に扣いて, 組織学的異型度・ 深達度と血清 CEA 值の関係をみると, Table 6に示す ように, 異型度, 深達度の悪化とともに平均值は高く なったが，推計学的には有意差は証明できなかった。 一方，転移の有無と血清 CEA 值の関係をみると (Table 7), 有転移群は無転移群に比べ有意 $(\mathrm{p}<0.05)$ に高值を示し, $10 \mathrm{ng} / \mathrm{ml}$ 以上を示す症例が $29 \%(4 / 14)$ にみられた。遠隔転移の出現は, 腫瘍の血管, リンパ 管内浸潤によるものと考兄られることから, 血清 CEA 值は腫瘍の脈管内浸潤を反映するものと考兄られた。

兵庫医科大学 RI センター診療部に沶ける血清 CEA 值の正常值 $3.0 \mathrm{ng} / \mathrm{ml}$ を正常上限値とした場合, TCC 全体では $31 \%(26 / 85)$ の陽性率であり，スクリー ニングテストとしての診断的価值は不充分であるが, 従来指摘されているように ${ }^{13) 15) 16)}$, 腫瘍の拡がり, 特に 脈管内浸潤を強く反映するものと考兄られる。

これに対し，尿膜管癌 3 例中 2 例が $5.0 \mathrm{ng} / \mathrm{ml}$ 以上 の高値を示し, 腫瘍内 CEA の結果と併せて考劣ると， 尿膜管癌ではTCCに比べCEAはより特異的な

Table 6 Relationship between Serum CEA Levels and Histological Grade, Pathological Stage in Transitional Cell Carcinoma of Bladder.

\begin{tabular}{l|r|c|c}
\hline \multirow{2}{*}{ TCC of Bladder } & $\begin{array}{c}\text { No. of } \\
\text { cases }\end{array}$ & $\begin{array}{c}\text { Serum CEA levels } \\
(\mathrm{ng} / \mathrm{ml})\end{array}$ & \multirow{2}{*}{$*$} \\
& & Mean \pm S.D. & \\
\hline Grade & 2 & $1.40 \pm 0.42$ & \multirow{2}{*}{ N.S.** } \\
G1 & 39 & $2.58 \pm 1.10$ & N.S.** \\
G2 & 18 & $3.19 \pm 3.50$ & \\
G3 & & & \\
Stage & 27 & $2.42 \pm 1.04$ & \multirow{2}{*}{ N.S.** } \\
pTis+pT1 & 32 & $2.99 \pm 2.72$ & \\
pT2/3+pT4 & &
\end{tabular}

* Statistical significance of differences between means (F test).

** Not significant. tumor markerであると考兄られる。

（4）尿中 CEA :

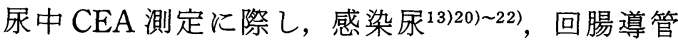

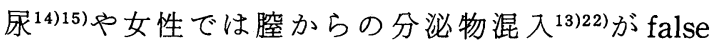
positive をもたらすことが指摘されている.そこで, 非 悪性腫瘍症例で細菌尿を伴わず，尿沈渣で白血球数5/ 毎以下の男子28例，女子16例を正常コントロールとし て測定したところ, 正常男子では $3.02 \pm 2.38 \mathrm{ng} / \mathrm{ml}$, 正 常女子では $4.59 \pm 4.73 \mathrm{ng} / \mathrm{ml}$ と男女差を認めた。今回 対象とした膀脱 TCC のらち, 尿路感染, 膿尿を除外で きたものは23例で全例男子であった，測定結果を Fig. 6 に示すが，膀胱 TCC では $8.01 \pm 10.42 \mathrm{ng} / \mathrm{ml}$ と正常 男子に比べ有意 $(\mathrm{p}<0.05)$ に高值を示した。 $7.8 \mathrm{ng} / \mathrm{ml}$ （mean士2S.D.）を正常上限值とした場合，その陽性率 は35\%であった。

膀胱 TCC に打ける組織学的異型度・深達度と尿中 CEA 值の関係をTable 8に示した。異型度と尿中 CEA 值の間には相関はみられなかった。これに対し，

Fig. 6 Levels of Urinary CEA in the Cases with Transitional Cell Carcinoma of Bladder and Normal Controls.

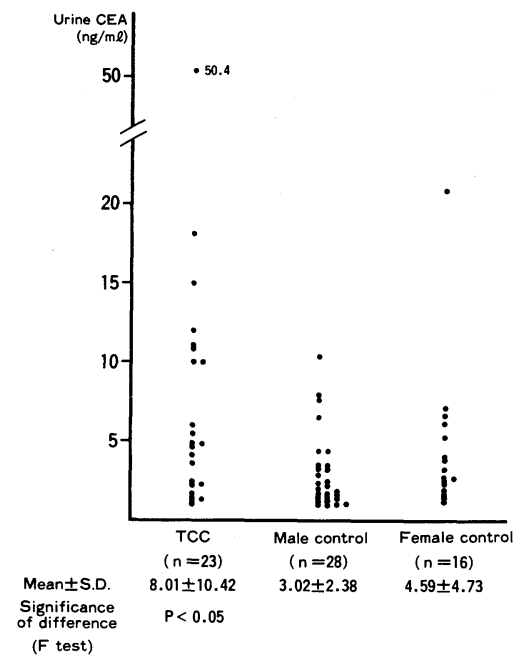

Table 7 Serum CEA Values in the Cases of TCC of Bladder with and without Metastasis.

\begin{tabular}{c|c|r|r|r|r|c}
\hline \multirow{2}{*}{ Metastasis } & \multirow{2}{*}{$\begin{array}{l}\text { No. of } \\
\text { cases }\end{array}$} & \multicolumn{4}{|c|}{ Serum CEA levels (ng/ml) } & \multirow{2}{*}{$*$} \\
\cline { 3 - 6 } & & $\leqq 3.0$ & $3.1-10.0$ & $>10.0$ & Mean \pm S.D. & \\
\hline Without & 59 & $45(76 \%)$ & $13(22 \%)$ & $1(2 \%)$ & $2.71 \pm 2.13$ & \multirow{2}{*}{$\mathrm{p}<0.05$} \\
With & 14 & $5(36 \%)$ & $5(36 \%)$ & $4(29 \%)$ & $10.51 \pm 13.40$ & \\
\hline
\end{tabular}

* Statistical significance of difference between means ( $\mathrm{F}$ test). 
深達度との関係では, low stage 群では3.55 $2.52 \mathrm{ng} /$ $\mathrm{ml}$ であったのに対し, high stage 群では $13.81 \pm 13.81$ $\mathrm{ng} / \mathrm{ml}$ で, らち $10 \mathrm{ng} / \mathrm{ml}$ 以上の高值を示したものが $70 \%$ 占めていた。両群の平均值の比較では有意 $(\mathrm{p}<$ 0.05)の差がみられ, 尿中 CEA 值と深達度の間には相 関があると考えられた。

（5）腫瘍内，血清拈よび尿中 CEA の相互関係：

PAP法による腫瘍内CEAの有無, および Radioimmunoassay 法による血清, 尿中 CEA 值の間 に直接の相関があるかどうかを検討した。腫瘍内 CEA 陽性群と陰性群の間で血清 CEA 值を比較検討する

Table 8 Relationship between Urine CEA Levels and Histological Grade, Pathological Stage in Transitional Cell Carcinoma of Bladder.

\begin{tabular}{l|r|c|c}
\hline \multirow{2}{*}{ TCC of Bladder } & \multirow{2}{*}{$\begin{array}{c}\text { No. of } \\
\text { cases }\end{array}$} & $\begin{array}{c}\text { Urine CEA levels } \\
(\mathrm{ng} / \mathrm{ml})\end{array}$ & \multirow{2}{*}{$*$} \\
\cline { 3 - 3 } & & Mean \pm S.D. & \\
\hline Grade & 4 & $3.38 \pm 1.92$ & \multirow{2}{*}{ N.S.** $^{*}$} \\
G1 & 13 & $9.55 \pm 13.01$ & N.S.** \\
G2 & 6 & $7.78 \pm 6.75$ & \\
G3 & & & \\
Stage & 13 & $3.55 \pm 2.52$ & P $<0.05$ \\
pTis+pT1 & 10 & $13.81 \pm 13.81$ & \\
pT2/3+pT4 & &
\end{tabular}

* Statistical significance of differences between means (F test).

** Not significant.
と, 膀胱 TCC 59例では, 陽性群と陰性群の間で血清 CEA 值の平均值に差がみられたが, 推計学的には有意 差は認められなかった (Table 9). 同様に, 膀胱 TCC 23例で尿中 CEA 值との関係をみる之, CEA 㓌性群の $90 \%(9 / 10)$ では $10 \mathrm{ng} / \mathrm{ml}$ 以下であり両群の平均值に 差がみられたものの, 推計学的には有意差は証明され なかった（Table 10）.

また, 同一症例に扣ける血清 CEA 值と尿中 CEA 值 の間の相関をみるために片対数表を用いて相関係数を 求めてみると, $\mathrm{y}=0.575+0.038 \mathrm{x}$ ( $\mathrm{y}=\log$ urine CEA, $\mathrm{x}=$ serum CEA, $\mathrm{n}=22)$, 相関係数 $\gamma=0.243$ が得られ, 有意の相関は証明されなかった ( $\mathrm{t}$ 検定).

以上のことから, 腫瘍内 CEA の有無, 血清および尿 中 CEA 值の三者の間には相関はないものと考兄られ た.

\section{考察}

CEA がGold ら ${ }^{12)}$ にって発見され，その Radioimmunoassay 法が確立されてからは, 血清をは じめ様々な体液中の微量な CEA の測定が可能とな り, 悪性腫瘍の診断に広く臨床応用されるようになっ た。諸家の報告6)7711)によれば,一般に, 結腸直腸癌, 朠癌，胆管癌などで高率に検出されるが，同時に肝機 能障害者, ある種の炎症性疾患, 契煙者などの非癌症 例にも少数ながら検出されることが判り，その cancer-specificity に問題点があることが指摘されるよう になった。

Table 9 Correlation between the Results of Immunoperoxidase Stain for CEA and Serum CEA Levels in Transitional Cell Carcinoma of Bladder.

\begin{tabular}{c|c|c|c|c|c}
\hline \multirow{2}{*}{ TCC of Bladder } & \multirow{2}{*}{$\begin{array}{l}\text { No. of } \\
\text { cases }\end{array}$} & \multicolumn{3}{|c|}{ Serum CEA values $(\mathrm{ng} / \mathrm{ml})$} & \multirow{2}{*}{$*$} \\
\cline { 3 - 5 } & & $\leqq 3.0$ & $>3.0$ & Mean \pm S.D. & \\
\hline Positive stain for CEA & 33 & $26(79 \%)$ & $7(21 \%)$ & $2.91 \pm 2.67$ & \multirow{2}{*}{ N.S.** } \\
Negative stain for CEA & 26 & $19(73 \%)$ & $7(27 \%)$ & $2.50 \pm 1.15$ & \\
\hline
\end{tabular}

* Statistical significance of difference between means ( $\mathrm{F}$ test).

** Not significant.

Table 10 Correlation between the Results of Immunoperoxidase Stain for CEA and Urine CEA Levels in Transitional Cell Carcinoma of Bladder.

\begin{tabular}{c|c|c|c|c|c}
\hline \multirow{2}{*}{ TCC of Bladder } & \multirow{2}{*}{$\begin{array}{l}\text { No. of } \\
\text { cases }\end{array}$} & \multicolumn{3}{|c|}{ Urine CEA levels (ng/ml) } & \multirow{2}{*}{$*$} \\
\cline { 3 - 5 } & & $<10.0$ & $\geqq 10.0$ & Mean \pm S.D. & \\
\hline Positive stain for CEA & 13 & $6(46 \%)$ & $7(54 \%)$ & $10.84 \pm 13.11$ & \multirow{2}{*}{ N.S. $^{* *}$} \\
Negative stain for CEA & 10 & $9(90 \%)$ & $1(10 \%)$ & $4.35 \pm 3.12$ & \\
\hline
\end{tabular}

* Statistical significance of difference between means ( $\mathrm{F}$ test).

** Not significant. 
CEA は, $\beta$-globulin 域に電気泳動される分子量約 20 万の糖蛋白で, 細胞膜表面に glycocalyx として存在 する30) とされるが，その化学的組成には不均一性がみ られ677), 複数の抗原決定基を有している. CEA と免疫 学的に交叉反応を示す $\mathrm{CEA}$ 関連物質として, $\mathrm{NCA}^{8)}$, $\mathrm{NFA}^{9)}, \mathrm{NCA}-2^{10)}$ などの存在が明らかにされ，CEA 分 子上にはこれらと共通の抗原決定基があるものと考兄 られている。このうち NCA は, 分子量約 5 万の糖蛋白 で，肺，脾，白血球など広く正常七卜組織中に含まれ て和り，これを除外してCEAを考学るのが一般的基 準となっている.今回 PAP法に用いた抗血清は, NCA を除外する目的で正常ヒト肺・脾の過塩素酸抽 出物沶よび正常ヒト血清で吸収処理したものを抗 CEA 血清として使用した。

近年, 組織内標的物質の存在を知る手段として免疫 組織化学的方法が一般的な方法として確立され，その 中でも Immunoperoxidase 法 ${ }^{25)}$ はその手技の簡便さ に加光鋭敏な方法であることから，ますます臨床病理 診断の一つの補助手段として頻用されるようになって 来ている. CEA についても, 免废組織化学的方法を用 いて腫瘍細胞内に拈ける局在に関する報告は多くみら れ31 33), 特に消化器癌に高率に証明される他に, 肺 癌34), 子宮癌 ${ }^{35)}$, 乳癌36)などにも検出されている。

泌尿器科領域においても, 膀胼腫湯について, Goldenberg $ら^{37}$ は indirect immunoperoxidase 法を用い て11\%に, Jautzke ら ${ }^{38)}$, Nakatsu ら ${ }^{50)}$ は PAP 法で 57\%，28\%に CEA 陽性細胞を証明しまた Wahren ${ }^{399}$ は䖝光抗体法で $45 \%$ に尿中剝離細胞中に陽性所見を得 ている。これらの報告で陽性率にバラッキがみられる のは, 染色方法, 標本の固定方法の違いによる可能性 を考慮しなければならない。一般に, Immunoperoxidase 法の中でも PAP 法は直接法や間接法に比べ標 的物質の検出感度は鋭敏とされ25)，またホルマリン固 定，パラフィン包埋材料よりも凍結後エタノール固定 材料の方が検出率が高い32) とされている。前述の Goldenberg らは間接法を用い染色し，Jautzke らは $4 \%$ フォルムアルデハイドによる固定後, プロナーゼ処理 を施し標的抗原の unmask 化をはかっている。 また， Wahren は螢光抗体法で CEA の検出を試みているた め, 単純に陽性率を比較することは難しいと思われる。

今回の PAP 法による結果から, 尿路系腫瘍の大部 分を占める TCC では, 腫瘍内 CEA は50\% (63/127) に陽性で，原発部位別にみると，膀胱腫瘍 $49 \%$ ，尿管 腫瘍 $55 \%$ ，腎孟腫瘍 $56 \%$ とその陽性率に有意の差はみ
られず，また腫瘍内 CEA の局在にも明らかな差がみ られなかったことは, CEA 産生能の面から腫瘍の類似 性を示するのとして特記される。CEA 陽性所見は, TCC では腫瘍細胞膜が強く染色されるもの (Fig. 1), および細胞質内が diffuse に染まるもの (Fig. 2) が観 察された。 TCCに招ける CEA の局在については, 細 胞膜表面や細胞質内に認められるといら報告37)38150)が あり，今回得られた結果はこれらを支持するもので あった。 結腸癌に拈いては, 腺腔内表面, 腺腔内分泌

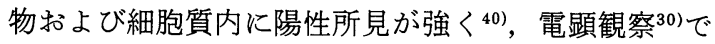
は glycocalyx として細胞膜表面に存在するとされて いる. 膀脱 ACで得られた所見はこれに極めて類似し ているものと考光られた。

TCC に拈いて, 腫湟内 CEA 陽性率が, G1 $0 \%$, G2 $50 \%, \mathrm{G} 365 \%$ と異型度の悪化とともに有意に高くなり (Table 2), 同様に pT1以下の low stage 群 $36 \%$ と pT2以上の high stage 群63\%の間で有意の差がみら れたこと (Table 3) や, 術後局所再発を来した症例に 有意に高率であったこと (Table 4)，さらに良性腫湯 である移行上皮乳頭腫では全例陰性であったこと (Table 1)などを併せて考光てみると, 腫瘍内 CEA の 存在は TCC の悪性度を表わす一つの parameter とな りらると考光られた. Jautzke ら ${ }^{38)}$ も膀胱 TCC 150例 について, 組織学的異型度呫よび深達度の悪化ととも に腫腸内 CEA 陽性率が高くなることを報告し, 同様 に Nakatsu ら ${ }^{50)}$ も異型度, 深達度, 予後の悪い群に CEA 陽性率が高いことを見出している。一方, Wahren ${ }^{39)}$, Nathrath ら ${ }^{49)}$ はこれとは逆に, 高分化癌 程強く CEA 陽性を示す細胞を有していると報告して いる，腫瘍の分化度と CEA の関係についての報告は 多くみられるが，未だ見解の一致はみていないようで ある. 結腸癌では, Denk ら ${ }^{40}$ 怯間接䖝光抗体法を用い て高分化癌に強陽性に検出されるのに対し, 低分化癌 では検出されないことを示し，このことからCEA は 腫瘍細胞膜の構成成分といらょりは分泌産物であるら こ推定している. Drewinko ら ${ }^{41)}$ は, 結腸癌培養細胞を 用いて細胞增殖周期に怙ける CEA 合成を検討した結 果, CEA は増殖期よりも非増殖期である G1 phase で 多く合成されることを報告し，このことから悪性度の 高い腫瘍程 CEA 合成が少なくなるとする考兊 ${ }^{39)}$ も る。これとは逆に, Sharkey ら ${ }^{42)}$ は結腸 polyp と結腸 癌を対象にして組織内 CEA を定量し, 癌や異型腺管 を伴う polypよりも, villousadenomatous polyp に多 くの CEA が含有されていたことから, 腫瘍の分化度 
と組織内 CEA 濃度には相関はないとしている．TCC について今回検討した結果は，腫瘍の悪性度が高くな る程 CEA 産生能が高くなるという説を支持するもの であった。

一般に, 腫瘍組織内 CEA 濃度は結腸癌では高い

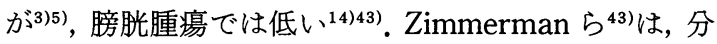
子量, 過塩素酸溶解性, Con-A 結合性などの点で, 膀 胱腫瘍組織中にも結腸癌由来 CEA と identical な CEA が存在することを明らかにしたが, その含有量は 極めて少量であったとしている．今回得られた結果 （Table 5）と諸家の報告3)514442)43) している腫瘍内 CEA 濃度の絶対値を比較することは, Khoo ら ${ }^{5)}$ も指 摘しているょうに, 抽出方法, 測定に用いた Radioimmunoassay 系の違いのために難しいと考学られるが, 膀羘 ACには720ng/g wet wt. という結腸腺癌に匹敵 する多量の Immunoreactive CEA が含まれたことは 注目に值する結果であった. AC と TCCでは腫瘍組織 内 CEA 量に大きな差がみられることや，消化器腺癌 では今回得られた TCCに拈ける結果とは逆に, 高分 化癌程腫瘍内 CEA が高率に検出されるとする報告が 多いことなどから, AC と TCCでは各々の CEA の代 謝・生合成過程が異なる可能性も考兄られる.

非癌膀脱粘膜中にも少量ではあるが Immunoreactive CEA が検出されたことは(Table 5), Martin らが指摘しているようにCEAのもつ cancerspecificity の問題点を示しているものと考兄られる. しかし, 非癌粘膜中の CEA については, 結腸癌症例で 腫瘍近傍粘膜には腫瘍から離れた部位の粘膜に比べ多 くの CEA が含まれたことから，これは腫瘍で生成さ れた CEA が非癌粘膜中に吸収された結果であろうと する報告5)31)もある。今回対象とした非癌膀胼粘膜は 膀胱腫瘍症例から得た検体であることから, 腫瘍中の CEA が吸收されたものを測定している可能性も否定 できないと考えられる。

膀胱 AC のうち尿膜管癌では, 高い腫瘍内 CEA 濃 度を有し（Table 5), PAP 法で全例に CEA が強陽性 に染色され（Table 1)，そして高い血中濃度を示した (Fig. 5). ФrjasÆter $ら^{16)}$ も, 膀胖および尿道原発腺癌 4 例で全例に血清 CEA 值の高値を認めたと報告して いる。これらのことから, 腺癌のうち特に尿膜管癌で は，TCCに比べて CEA はより特異的な marker であ ると考えられる，これに対し，中腎癌は1例ではある が PAP 法で CEA は陰性であり, 腺癌の中でも両腫瘍 の発生母地が内胚葉由来, 中胚葉由来 ${ }^{44)}$ と考学られる
ことから興味深い結果であった。

膀脱 SCC では， 5 例全例に PAP 法で腫瘍内 CEA が証明された。他藏器原発 SCC の中でも, 皮膚, 喉頭, 食道原発 SCC ではCEA 陰性であったといら報告 ${ }^{31)}$ と比べて今回の結果は, 一般に膀胼 SCC の予後が悪い ことと併せて注目すべき結果であった。

尿路系腫瘍における血清 CEA については，その診

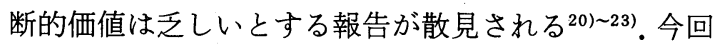
の結果でも (Fig. 5), 膀胼 TCC では良性疾患群に比べ 有意に高值を示したものの, その陽性率は僅か $32 \%$ (23/73) で，スクリーニングテストとしての意義は乏 しいと言わざるを得ない。しかし, 遠隔転移の出現と ともに有意に高値を示し, 特に $10 \mathrm{ng} / \mathrm{ml}$ 以上を示す場 合転移の存在を強く疑うべきである (Table 7). 血清 CEA 值は, PAP 法による腫瘍内 CEA の有無とは相 関せず (Table 9), 転移の有無と相関がみられたこと から, 血清 CEA 值を左右する因子は, CEA 産生細胞 の多少より ${ }^{32245)}$, 腫瘍の脈管内浸潤の有無 ${ }^{42)}$ である と考えられた。

尿中 CEA については, 治療経過中の経時的測定に おいて放射線療法後に腫瘍細胞破壊によって一過性に 最高值を示すことや46), 膀胱腫瘍症例の腎瘦尿では低 值であることから ${ }^{47)}$, 血流・腎を介して尿中に排泄され るものではなく, 直接腫瘍細胞から放出されるものと 考学られる. しかし, 尿路感染などの要因で false positive を呈する例が多く, 限られた症例にのみしか適用 できないという問題点を有している。 上記の要因が除 外できると，尿細胞診など他の検査法との併用でスク リーニングテストとしての有用性が増すものと考克ら れる ${ }^{14)}$. 膀胱 TCC に拈いて，尿中 CEA 值はPAP 法 による腫腸内 CEA の有無 (Table 10) 拈よび組織学的 異型度 (Table 8) との相関は認められなかったが, 深 達度との関係で high stage 群は low stage 群に比べ 有意に高値を示した。このことは, 尿中 CEA 值は腫瘍 の膀脂腔内露出面積の大小 ${ }^{15) 46)}$ の他に, 浸潤癌程細胞 間結合が弱く剥離し易いといら性格 ${ }^{48)} 反$ 反映している ものと考えられる。

以上述べてきたように，PAP法による腫瘍組織内 CEA の存在, 血清 CEA 值および尿中 CEA 值は, それ ぞれが腫瘍の病態を表わす tumor markerであると考 えられるが，これら三者の間に相関は証明されなかっ た. 即ち, 腫漡内 CEA の存在は組織学的異型度, 深達 度, 再発の有無の点から予後を予知する手がかりとな り得るし, また血清拉よび尿中 CEA は各々, 脈管内浸 
潤の有無, 腫瘍の浸達度を表わす tumor marker とし て有用であると考学らる。

今後, より尿路腫瘍に特異的な腫瘍抗原としての CEA の解明がすすめば，診断・予後判定に一層有用な tumor marker となりらるものと期待される.

\section{結語}

原発性尿路腫瘍を対象として, 腫瘍内 CEA の存在 を酵素抗体法 (PAP 法)を用いて免疫組織化学的に検 討した結果, 移行上皮癌, 腺癌, 扁平上皮癌に検出さ れたが，その他の悪性腫瘍や良性病変には検出されな かった.

尿路系腫瘍の大部分を占める移行上皮癌では, 腫瘍 内 CEA の存在は, 異型度, 深達度および局所再発の有 無之の間で相関がみられ，腫瘍の悪性度を表わす parameter となりらると考觉られたが, Radioimmunoassay 法により測定した血清拈よび尿中 CEA 值との間 には相関は証明されなかった。

尿膜管癌では, CEA は腫瘍内濃度, 血中濃度ともに 高く, CEAのもつ特異性は大きいと考光られた。

稿を終えるに当り, 御指導, 御校閲を賜った恩師生駒文彦 教授に深甚の謝意を表します。 また, 病理学的検討に際し御 指導を頂きしし兵庫医科大学病院病理部植松邦夫教授, ならびに摡切なる御助言を頂きました兵庫医科大学 RI セ ンター診療部福地稔助教授に深謝いたします。

\section{文献}

1) Gold, P. and Freedman, S.O.: Demonstration of tumor-specific antigens in human colonic carcinomata by immunological tolerance and absorption techniques. J. Exp. Med., 121, 439-462, 1965.

2) Gold, P. and Freedman, S.O.: Specific carcinoembryonic antigens of the human digestive system. J. Exp. Med., 122, 467-481, 1965.

3) Martin, F. and Martin, M.S.: Radioimmunoassay of carcinoembryonic antigen in extracts of human colon and stomach. Int. J. Cancer, 9, 641-647, 1972.

4) Burtin, P., von Kleist, S., Sabine, M.C. and King, M.: Immunohistological localization of carcinoembryonic antigen and nonspecific cross-reacting antigen in gastrointestinal normal and tumoral tissues. Cancer Res., 33, 3299-3305, 1973.

5) Khoo, S.K., Warner, N.L., Lie, J.T. and Mackay, I.R.: Carcinoembryonic antigenic activity of tissue extracts: A quantitative study of malignant and benign neoplasms, cirrhotic liver, normal adult and fetal organs. Int. J.
Cancer, 11, 681-687, 1973.

6) Neville, A.M. and Laurence, D.J.R. : Report of the workshop on the carcinoembryonic antigen (CEA): The present position and proposals for future investigation. Int. J. Cancer, 14, 1-18, 1974.

7) von Kleist, S. and Burtin, P.: The carcinoembryonic antigen (CEA) and other carcinofetal antigens in gastrointestinal cancers and benign diseases. in Progress in Gastroenterology, Glass, G.B.J., Vol. 3, p595, Grune \& Stratton Inc., New York, 1977.

8) von Kleist, S., Chavanel, G. and Burtin, P.: Identification of an antigen from normal human tissue that crossreacts with the carcinoembryonic antigen. Proc. Natl. Acad. Sci., 69, 2492-2494, 1972.

9) Matsuoka, Y., Hara, M., Takatsu, K. and Kitagawa, M.: Presence of antigen related to the carcinoembryonic antigen in feces of normal adults. Gann, 64, 203-206, 1973.

10) Burtin, P., Chavanel, G. and Hirsch-Marie, H.: Characterization of a second normal antigen that cross-reacts with CEA. J. Immunol., 111, 1926-1928, 1973.

11) Hirai, H.: A collaborative clinical study of carcinoembryonic antigen in Japan. Cancer Res., 37, 2267-2274, 1977.

12) Reynoso, G., Chu, T.M., Guinan, P. and Murphy, G.P.: Carcinoembryonic antigen in patients with tumors of the urogenital tract. Cancer, 30 , $1-4,1972$.

13) Hall, R.R., Laurence, D.J.R., Neville, A.M. and Wallace, D.M.: Carcinoembryonic antigen and urothelial carcinoma. Brit. J. Urol., 45, 88-92, 1973.

14) Fraser, R.A., Ravry, M.J., Segura, J.W. and Go, V.L.W.: Clinical evaluation of urinary and serum carcinoembryonic antigen in bladder cancer. J. Urol., 114, 226-229, 1975.

15) Ionescu, G., Romas, N.A., Ionascu, L., Bennet, S., Tannenbaum, M., Veenema, R.J. and Lattimer, J.K.: Carcinoembryonic antigen and bladder carcinoma. J. Urol., 115, 46-48, 1976.

16) Фrjas $\notin$ ter, H., Fosså, S.D., Schj $\phi 1$ seth, S.A. and FjÆstad, K.: Carcinoembryonic antigen (CEA) in plasma of patients with carcinoma of the bladder/urethra. Cancer, 42, 287-295, 1978.

17）木戸 晃, 町田豊平, 三木 誠, 大石幸彦, 上田正 山, 柳沢宗利, 飯尾正宏, 山田英夫, 末広牧子：泌 尿器科領域の悪性腫揚における CEA の検討. 日泌 
尿会誌，68，751-757，1977.

18）門脇照雄, 永井信夫, 金子茂男, 井口正典, 郡健二 郎, 南 光二, 秋山隆弘, 八竹 直, 栗田 孝: 泌 尿器科領域に拈ける CEA (第 1 報). 血中，尿中の CEA 值について. 日泌尿会誌, 69, 539-542, 1978.

19）角田和之, 宮崎良春, 山口秋人, 南里和成, 原 孝 彦, 原 三信：泌尿器科領域における CEA の検 討，西日泌尿，42，323-329，1980.

20) Colleen, S., Ek, A., Gullberg, B., Johansson, B. G., Lindberg, L.G. and Olsson, A.M. : Carcinoembryonic antigen in urine in patients with urothelial carcinoma. Scand. J. Urol. Nephrol., 13, 149-153, 1979.

21) Glashan, R.W., Higgins, E. and Neville, A.M. : The clinical value of plasma and urinary carcinoembryonic antigen (CEA) assays in patients with haematuria and urothelial carcinoma. Eur. Urol., 6, 344-346, 1980.

22) Hall, R.R.: Carcinoembryonic antigen and urological carcinoma. A review after 7 years. Brit. J. Urol., 52, 166, 1980.

23）大橋輝久, 東條俊司, 武田克治, 公文裕巳, 森岡政 明, 松村陽右, 大森弘之, 陶山文三, 広中孝作：尿 路悪性腫瘍患者における血清 Ferritin, CEA， $\beta_{2}$ MG, PAP に関する検討. 泌尿紀要, 29, 141－153, 1983.

24) Sternberger, L.A., Hardy, P.H., Cuculis, J.J. and Meyer, H.G.: The unlabeled antibody enzyme method of immunohistochemistry.: Preparation and properties of soluble antigen-antibody complex (horseradish peroxidase-antihorseradish peroxidase) and its use in identification of spirochetes. J. Histochem. Cytochem., 18, 315-333, 1970.

25) DeLellis, R.A., Sternberger, L.A. Mann, R.B., Banks, P.M. and Nakane, P.K.: Immunoperoxidase technics in diagnostic pathology. Report of a workshop sponsored by the National Cancer Institute. Am. J. Clin. Pathol., 71, 483-488, 1979.

26) von Kleist, S. and Burtin, P.: Isolation of a fetal antigen from human colonic tumors. Cancer Res., 29, 1961-1964, 1969.

27) Melamed, M.R., Voutsa, N.G. and Grabstald, H. : Natural history and clinical behavior of in situ carcinoma of the human urinary bladder. Cancer 17, 1533-1545, 1964.

28) Farrow, G.M., Utz, D.C., Rife, C.C. and Greene, L.F.: Clinical observations on sixty-nine cases of in situ carcinoma of the urinary bladder. Cancer Res., 37, 2794-2798, 1977.

29) Kanokogi, M., Uematsu, K., Kakudo, K.,
Shimada, K. and Ikoma, F.: Mesonephric adencarcinoma of the urinary bladder: An autopsy case. J. Surg. Oncol., 22, 118-120, 1983.

30) Gold, P., Krupey, J. and Ansari, H.: Position of the Carcinoembryonic antigen of the human digestive system in ultrastructure of tumor cell surface. J. Natl. Cancer Inst., 45, 219-225, 1970.

31) Goldenberg, D.M., Sharkey, R.M. and Primus, F.J. : Immunocytochemical detection of carcinoembryonic antigen in conventional histopathology specimens. Camcer, 42, 1546-1553, 1978.

32) Goldenberg, D.M., Sharkey, R.M. and Primus, F.J.: Carcinoembryonic antigen in histopathology: Immunoperxidase staining of conventional tissue sections. J. Natl. Cancer Inst., 57, 11-22, 1976.

33) Primus, F.J., Sharkey, R.M., Hansen, H.J. and Goldenberg, D.M. : Immunoperoxidase detection of carcinoembryonic antigen. An overview. Cancer, 42, 1540-1545, 1978.

34) Goslin, R.H., O’brien, M.J., Skarin, A.T. and Zamcheck, N.: Immunocytochemical staining for CEA in small cell carcinoma of lung predicts clinical usefuless of the plasma assay. Cancer, 52, 301-306, 1983.

35) von Nagell, J.R., Gay, H.E.C., Donaldson, E.S., Hanson, M., Powell, D.F. and Goldenberg, D. M. : Carcinoembryonic antigen in carcinoma of the uterine cervix. Cancer, 49, 379-383, 1982.

36) Kuhajda, F.P., Offutt, L.E. and Mendelsohn, G. : The distribution of carcinoembryonic antigen in breast carcinoma. Cancer, 52, 1257-1264, 1983.

37) Goldenberg, D.M. and Wahren, B.: Immunoperoxidase staining of carcinoembryonic antigen in urinary bladder cancer. Urol. Res., 6 , 211-214, 1978.

38) Jautzke, G. and Altenaehr, E. : Immunohistochemical demonstration of carcinoembryonic antigen (CEA) and its correlation with grading and staging on tissue sections of urinary bladder carcinomas. Cancer, 50, 2052-2056, 1982.

39) Wahren, B. : Cellular content of carcinoembryonic antigen in urothelial carcinoma. Cancer, 42, 1533-1539, 1978.

40) Denk, H., Tappeiner, G., Eckerstorfer, R. and Holzner, J.H.: Carcinoembryonic antigen (CEA) in gastrointestinal and extragastrointestinal tumors and its relationship to tumor-cell differentiation. Int. J. Cancer, 10, 262-272, 1972. 
41) Drewinko, B. and Yang, L.Y.: Restriction of CEA synthesis to the stationary phase of growth of cultured human colon carcinoma cells. Exp. Cell Res., 101, 414-416, 1976.

42) Sharkey, R.M., Hagihara, P.F. and Goldenberg, D.M. : Localization by immunoperoxidase and estimation by radioimmunoassay of carcinoembryonic antigen in colonic polyp. Brit. J. Cancer, 35, 179-189, 1977.

43) Zimmerman, R. and Hammarström, S.: Isolation of CEA-like meterial from urinary bladder carcinoma. Urol. Res., 6, 215-219, 1978.

44) Dow, J.A. and Young, J.D. Jr.: Mesonephric adenocarcinoma of the bladder. J. Urol., 100, 466-469, 1968.

45) Lewis, J.C.M. and Keep, P.A. : Relationship of serum CEA levels to tumor size and CEA content in nude mice bearing colonic-tumor xenografts. Brit. J. Cancer, 44, 381-387, 1981.

46) Wahren, B., Nilsson, B. and Zimmerman, R.: Urinary CEA for perdiction of survival time and recurrence in bladder cancer. Cancer, 50,
139-145, 1982.

47) Zimmerman, R., Wahren, B. and Edsmyr, F.: Assessment of serial CEA determinations in urine of patients with bladder carcinoma. Cancer, 46, 1802-1809, 1980.

48) Alroy, J., Pauli, B.U . and Weinstein, R.S. : Correlation between numbers of desmosomes and the aggressiveness of transitional cell carcinoma in human urinary bladder. Cancer, 47 , 104-112, 1981.

49) Nathrath, W.B.J., Arnholdt, H. and Wilson, P. D.: Keratin, luminal epithelial antigen and carcinoembryonic antigen in human urinary bladder carcinomas. An immunohistochemical study. Path. Res. Pract., 175, 299-307, 1982.

50) Nakatsu, H., Kobayashi, I., Onishi, Y., Igawa, M., Ito, H., Tahara, E. and Nihira, H. : ABO (H) blood group antigens and carcinoembryonic antigens as indicators of malignant potential in patients with transitional cell carcinoma of the bladder. J. Urol., 131, 252-257, 1984.

(1984年 3 月 1 日受付) 